\title{
PENGARUH LINGKUNGAN BELAJAR DAN PERAN GURU TERHADAP MOTIVASI BELAJAR SISWA PADA PELAJARAN EKONOMI DI SMA NEGERI 1 MASBAGIK TAHUN PELAJARAN 2016/2017
}

\author{
Danang Prio Utomo ${ }^{1}$, M. Zainul Majdi ${ }^{2}$, Yatni Ayu Rizqi ${ }^{3}$ \\ ${ }^{1}$ Prodi Pendidikan Ekonomi FKIP Universitas Hamzanwadi \\ email: danang_irenk@yahoo.com \\ ${ }^{2}$ Prodi Pendidikan Ekonomi FKIP Universitas Hamzanwadi \\ email: muhammadzainulmajdi@ hamzanwadi.ac.id \\ ${ }^{3}$ Prodi Pendidikan Ekonomi FKIP Universitas Hamzanwadi \\ email:yatniayu3ku2@gmail.com
}

\begin{abstract}
ABSTRAK:
Penelitian ini bertujuan untuk mengetahui pengaruh lingkungan belajar dan peran guru terhadap motivasi belajar siswa ekonomi di SMAN 1 Masbagik Tahun Pelajaran 2015/2016. Penelitian ini merupakan penelitian expostfacto dengan menggunakan pendekatan kuantitatif. Populasi penelitian ini adalah kelas XI IPS SMAN 1 Masbagik tahun pelajaran 2015/ 2016 dengan sampel penelitian sebesar 52 siswa yang diambil dengan teknik sampel proposional dan teknik random samling. Pengumpulan data lingkungan belajar dan peran guru dan motivasi belajar menggunakan instrumen dengan menyebarkan angket. Data dianalisis dengan teknik analisis korelasi parsial dan analisis regresi ganda. Hasil penelitian menunjukkan bahwa : 1). perhitungan uji koefisien regresi dengan nilai koefisien regresi variabel lingkungan belajar dengan nilai t-hitung sebesar 0,989 dan tingkat kesalahan signifikan 0,327 yang lebih kecil dari tingkat signifikan yang telah ditentukan $(0,05)$. Maka Ha diterima dan dapat disimpulkan bahwa variabel lingkungan belajar berpengaruh signifikan terhadap motivasi belajar siswa pada pelajaran ekonomi Di SMAN 1 Masbagik Tahun Pelajaran 2015/2016. 2). perhitungan uji koefisien regresi dengan nilai koefisien regresi variabel peran guru dengan nilai t-hitung sebesar 2,189 dan tingkat kesalahan signifikan 0,033 yang lebih kecil dari tingkat signifikan yang telah ditentukan $(0,05)$. Maka Ha diterima dan dapat disimpulkan bahwa variabel peran guru berpengaruh signifikan terhadap motivasi belajar siswa pada pelajaran ekonomi Di SMAN 1 Masbagik Tahun Pelajaran 2015/2016. 3). perhitungan uji koefisien regresi dengan nilai koefisien regresi variabel lingkungan belajar dan peran guru dengan nilai t hitung sebesar 6,537 dan tingkat kesalahan signifikan 0,003 yang lebih kecil dari tingkat signifikan yang telah ditentukan $(0,05)$. Maka Ha diterima dan dapat disimpulkan bahwa variabel lingkungan belajar dan peran guru berpengaruh signifikan terhadap motivasi belajar siswa pada pelajaran ekonomi Di SMAN 1 Masbagik Tahun Pelajaran 2015/2016.
\end{abstract}

Kata Kunci: Lingkungan Belajar, Peran Guru, Motivasi Belajar 


\section{PENDAHULUAN}

Belajar pada hakekatnya adalah suatu interaksi antara individu dan lingkungan. Lingkungan menyediakan ransangan (stimulus) terhadap individu dan sebaliknya individu memberikan respons terhadap lingkungan dalam proses interaksi itu dapat terjadi perubahan pada diri individu berupa perubahan tingkah laku. Lingkungan dalam pengertian umum berarti situasi disekitar kita. Dalam pendidikan lingkungan adalah semua faktor yang terdapat diluar diri anak dan yang mempunyai arti bagi pengembangannya serta senantiasa memberikan pengaruh terhadap dirinya (Baharuddin, 2007:68).

Lingkungan belajar sangat berpengaruh terhadap motivasi belajar siswa karena lingkungan belajar yang aman akan memberikan motivasi belajar siswa agar lebih rajin belajar. Apabila lingkungan belajar yang kurang optimal akan berpengaruh besar terhadap motivasi belajar disekolah tersebut. Sehinnga peran guru sangat diperlukan untuk mlihat bagaimana lingkungan belajar yang ada didalam sekolah maupun diluar sekolah. Istilah motivasi berasal dari bahasa latin yaitu movere yang dalam bahasa inggris berarti to move adalah kata kerja yang artinya menggerakkan. Motivasi itu sendiri dalam bahasa inggris adalah motivation yaitu sebuah kata benda yang artinya penggerakkan. Jarang juga dikatakan bahwa seorang siswa gagal dalam mata pelajaran tertentu karena kurang motivasi (Gintings, 2008:86).

SMAN 1 Masbagik bisa dikatakan memiliki lingkungan belajar yang aman dan optimal sehingga siswa-siswi sangat termotivasi dalam proses belajar. Meskipun begitu guru tidak bisa lepas tangan begitu saja untuk memberikan motivasi pada siswa-siswanya, peran guru masih sangat dibutuhkan untuk lebih meningkatkan motivasi belajar siswa-siswi di SMAN 1 Masbagik baik didalam sekolah maupun diluar sekolah.

Adapun rumusan masalah yang di tetapkan dalam penelitian ini adalah sebagai berikut:

1. Apakah lingkungan belajar berpengaruh positif dan signifikan terhadap motivasi belajar siswa pada pelajaran Ekonomi SMAN 1 Masbagik Tahun Pelajaran 2015/2016? 
2. Apakah peran guru berpengaruh positif dan signifikan terhadap motivasi belajar siswa pada pelajaran Ekonomi SMAN 1 Masbagik Tahun Pelajaran $2015 / 2016 ?$

3. Apakah lingkungan belajar dan peran guru berpengaruh positif dan signifikan terhadap motivasi belajar siswa pada pelajaran Ekonomi SMAN 1 Masbagik Tahun Pelajaran 2015/2016?

Lingkungan dalam arti sempit adalah alam sekitar di luar diri individu atau manusia. Lingkungan itu mencakup segala material dan stimulus di dalam dan di luar individu, baik yang bersifat fisiologis, psikologis, maupun sosio-kultural (Dalyono, 2007: 129). Sedangkan menurut Sidi (2005:148), "Lingkungan belajar sangat berperan dalam menciptakan suasana belajar menyenangkan". Lingkungan tersebut dapat meningkatkan keaktifan belajar, oleh karena itu lingkungan belajar perlu di tata semestinya. Lingkungan ini mencakup dua hal utama, yaitu lingkungan fisik dan lingkungan sosial, kedua aspek lingkungan tersebut dalam proses pembelajaran haruslah saling mendukung, sehingga siswa merasa krasan di sekolah dan mau mengikuti proses pembelajaran secara sadar dan bukan karena tekanan ataupun keterpaksaan. Sehingga menciptakan suasana belajar menyenangkan. Lingkungan tersebut dapat meningkatkan keaktifan belajar, oleh karena itu lingkungan belajar perlu di tata semestinya.

Slameto (2005: 60) mengemukakan bahwa lingkungan belajar siswa yang berpengaruh terhadap hasil belajar siswa terdiri dari lingkungan keluarga, lingkungan sekolah dan lingkungan masyarakat. Guru adalah semua orang yang berwewenang dan bertanggung jawab terhadap pendidikan murid-murid, baik secara individual atau klasikal, baik di sekolah maupun di luar sekolah (Syaiful, 2009: 21). Guru adalah pendidik, yang menjadi tokoh, panutan, dan indikasi bagi peserta didik, dan lingkungannya. (Mulyasa, 2008: 37). Dari beberapa pendapat diatas maka secara rinci peranan guru dalam kegiatan belajar-mengajar, secara singkat dapat disebutkan sebagai berikut:

1. Informator

2. Organisator

3. Motivator 
4. Director

5. Inisiator

6. Transmitter

7. Fasilitator

8. Mediator

9. Evaluator

Menurut Sardiman (2005:73) "motivasi adalah daya penggerak dari dalam dan di dalam subjek untuk melakukan aktivitas-aktivitas tertentu demi mencapai suatu tujuan. Motivasi dibedakan menjadi dua jenis, yaitu: Motivasi Intrinsik dan Motivasi Ekstrinsik. Sedangkan menurut Mc Donald dan Soemanto (2005:203) menyatakan bahwa "motivasi adalah suatu perubahan tenaga dalam diri atau pribadi seseorang yang ditandai oleh dorongan efektif dan reaksi-reaksi dalam usaha mencapai tujuan.

\section{METODE PENELITIAN}

Penelitian ini tergolong jenis penelitian ex post facto. "Penelitian ex post facto adalah suatu penelitian yang dilakukan untuk meneliti peristiwa-peristiwa yang telah terjadi dan kemudian melihat kebelakang untuk mengetahui faktorfaktor yang dapat menimbulkan kejadian tersebut"(Sugiono, 2008:39). Adapun pendekatan yang digunakan dalam penelitian ini adalah pendekatan kuantitatif yang menganalisis data dengan alat analisis statistik. Selain itu juga menggunakan analisis deskriptif dimana analisis deskriptif digunakan untuk mengungkapkan bagaimana lingkungan belajar dan peran guru terhadap motivasi belajar siswa.

Populasi ialah semua nilai baik hasil perhitungan maupun pengukuran, baik kuantitatif maupun kualitatif, dari karakteristik tertentu mengenai sekelompok objek yang lengkap dan jelas (Husaini Usman. 2006 : 181). Sampel menurut Suharsimi (2006:131) adalah " bagian atau wakil dari populasi yang diteliti". Pengambilan sampel dapat menggambarkan populasi yang sebenarnya. Untuk menentukan sampel, maka diperlukan teknik pengambilan sampel teknik pengambilan sampel yang digunakan dalam penelitian ini adalah proporsional random sampling yang merupakan gabungan dari teknik sampel proposional dan 
teknik random sampling. Menurut Margono sampel proposional menunjukkan kepada perbandingan penarikan sampel dari beberapa sub populasi yang tidak sama jumlahnya. Sedangkan random sampling adalah pengambilan sampel secara random dimana semua individu dalam populasi, baik secara sendiri-sendiri ataupun bersama-sama diberi kesempatan yang sama untuk dipilih menjadi anggota sampel.

Data dalam penelitian ini diperoleh dengan menyebarkan angket atau kuisioner yang dirancang oleh peneliti yang merupakan seperangkat pertanyaan atau pernyataan yang dijabarkan dari kontruk konsep masing-masing variabel. Kuisioner tersebut kemudian diberikan kepada responden dan memberikan kesempatan kepada responden untuk memberikan jawaban atas instrumen tersebut, dan terakhir mengumpulkan instrumen untuk dianalisis lebih lanjut.

Teknik analisis ini digunakan untuk mendesripsikan informasi atau data yang diperoleh dari hasil perhitungan komputer dengan program SPSS versi 16 for windows. Hasil perhitungan komputer tersebut meliputi rerata (mean), simpangan baku, modus, median, rentang skor maksimum dan minimum untuk setiap variabel. Dalam analisis deskriptif ini, skor data yang diperoleh dari data penelitian secara keseluruhan dideskripsikan dalam bentik tabel distribusi frekuensi. Pendistribusian itu akan dibuat dengan cara menentukan kelas interval terlebih dahulu. Penetuan kelas interval mengacu pada kurva normal dan diusahakan sesuai mengikuti aturan struges.

\section{HASIL DAN PEMBAHASAN}

Berdasarkan ringkasan hasil penelitian di atas diketahui bahwa terdapat pengaruh positif dan signifikan lingkungan belajar terhadap motivasi Belajar siswa pada mata pelajaran ekonomi di SMAN 1 Masbagik. Dari hasil analisis dengan menggunakan bantuan komputer program SPSS Statistics 16.00 for windows, yaitu 0,989 dengan signifikasi $0,327<0,05$. interprestasi hasil tersebut melalui persamaan regresi ganda adalah apabila lingkungan belajar (X1) dan motivasi belajar (Y) diukur dengan instrumen yang dikembangkan dalam penelitian ini, maka setiap kenaikan lingkungan belajar (X1) akan diikuti oleh kenaikan satu tingkat dukungan motivasi belajar (Y) sebesar 0,061 atau 16,1\%. Peningkatan ini 
sangat berarti apabila lingkungan belajar dapat mendukung proses belajar mengajar. Hasil tersebut menunjukkan bahwa lingkungan belajar berpengaruh signifikansi terhadap motivasi Belajar siswa pada mata pelajaran ekonomi di SMAN 1 Masbagik.

Berdasarkan ringkasan hasil penelitian di atas diketahui bahwa terdapat pengaruh positif dan signifikan peran guru terhadap motivasi Belajar siswa pada mata pelajaran ekonomi di SMAN 1 Masbagik. Dari hasil analisis dengan menggunakan bantuan komputer program SPSS Statistics 16.00 for windows, yaitu 2,189 dengan signifikasi $0,033<0,05$. interprestasi hasil tersebut melalui persamaan regresi ganda adalah apabila peran guru (X2) dan motivasi belajar(Y) diukur dengan instrumen yang dikembangkan dalam penelitian ini, maka setiap kenaikan peran guru (X2) akan diikuti oleh kenaikan satu tingkat didukung oleh motivas ibelajar sebesar 0,273 atau $27.3 \%$. Hasil tersebut menunjukkan bahwa peran guru berpengaruh signifikansi terhadap motivasi Belajar siswa pada mata pelajaran ekonomi di SMAN 1 Masbagik.

Berdasarkan ringkasan hasil penelitian menunjukkan bahwa terdapat pengaruh positif dan signifikan lingkungan belajar dan peran guru secara bersamasama terhadap motivasi Belajar siswa pada mata pelajaran ekonomi di SMAN 1 Masbagik. Dari hasil analisis dengan menggunakan bantuan komputer program SPSS Statistics 16.00 for windows, yang ditunjukkan oleh 12 2730,0610,,59910

YX dengan harga $\mathrm{F}$ sebesar 6,537 dengan taraf signifikasi masing-masing $0.003<0.05=\mathrm{a}$. Interprestasi persamaan tersebut adalah apabila variabel lingkungan belajar (X1), peran guru (X2) dan motivasi belajar (Y) diukur dengan intrumen yang dikembangkan dalam penelitian ini, maka setiap kenaikan satu tingkat pada variabel lingkungan belajar (X1), peran guru (X2) akan diikuti oleh kenaikan tingkat dukungan motivasi belajar (Y) sebesar 0,061 atau 6,1\% oleh variabel lingkungan belajar (X1), 0,273 atau 27.3\% oleh variabel peran guru (X2). Apabila dikaitkan dengan koefisien determinasi antara hubungan yang ditimbulkan oleh variabel-variabel tersebut terhadap motivasi belajar dimana kekuatan hubungan ketiga variabel terkat dengan motivasi belajar ditunjukkan oleh koefisien korelasi anda $4590,12 \square \mathrm{yR}$,sementara koefisien determinasi $2110,122 \square$ yR yang 
berarti bahwa sebesar 21,1\% lingkungan belajar (X1), peran guru (X2) dan berpengaruh terhadap motivasi belajar (Y) dan sisanya 78,9\% dipengaruhi oleh faktor lain. Yang berarti hasil penelitian menunjukkan bahwa terdapat pengaruh positif dan signifikan lingkungan belajar dan peran guru secara bersama-sama terhadap motivasi Belajar siswa pada mata pelajaran ekonomi di SMAN 1 Masbagik.

\section{DAFTAR RUJUKAN}

Ahmadi, Fatah. 2012. Makalah Peran dan Fungsi Guru, (online), (http://edukasi.kompasiana.com/2012/04/27/, diakses 27 April 2012)

Arikunto, Suharsimi. (2006). Prosedur Penelitian Suatu Pendekatan Praktek.Jakarta:Rineka Cipta.

Fatah Ahmadi, Peran dan Fungsi Guru: 18 Juli 2012: Kompasiana

Hamzam B. Uno, 2011. Teori Motivasi \& Pengukurannya (Analisis di Bidang Pendidikan). Penerbit PT Bumi Akasara : Jakarta.

Nurdin, Muhammmad. 2010. Kiat Menjadi Guru Profesional. Yogyakarta: AR. Ruzz Media Group

Sardiman. 2011. Interaksi dan Motivasi Belajar Mengajar. Jakarta: Rajawali Press Slameto. 2005. Belajar dan Faktor-Faktor yang Mempengaruhinya. Jakarta: PT Rineka Cipta

Sugiono. 2008. Metode Penelitian Pendidikan. Bandung: Alfabeta 